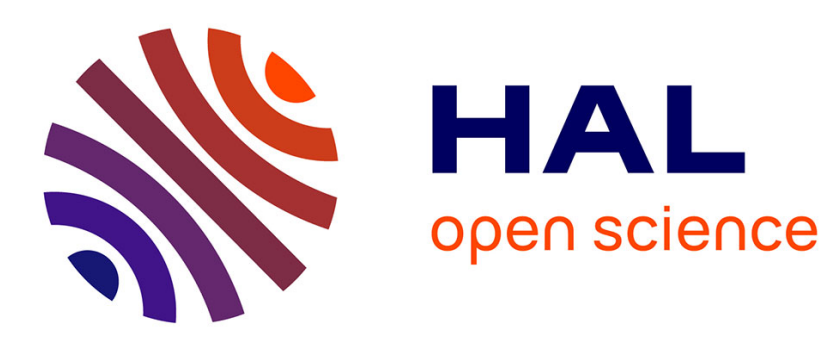

\title{
History as an Obstacle: Impact of Temporal-Based Social Categorizations on Polish-Jewish Intergroup Contact
}

\author{
Michal Bilewicz
}

\section{To cite this version:}

Michal Bilewicz. History as an Obstacle: Impact of Temporal-Based Social Categorizations on PolishJewish Intergroup Contact. Group Processes and Intergroup Relations, 2007, 10 (4), pp.551-563. $10.1177 / 1368430207081540$. hal-00571666

\section{HAL Id: hal-00571666 https://hal.science/hal-00571666}

Submitted on 1 Mar 2011

HAL is a multi-disciplinary open access archive for the deposit and dissemination of scientific research documents, whether they are published or not. The documents may come from teaching and research institutions in France or abroad, or from public or private research centers.
L'archive ouverte pluridisciplinaire HAL, est destinée au dépôt et à la diffusion de documents scientifiques de niveau recherche, publiés ou non, émanant des établissements d'enseignement et de recherche français ou étrangers, des laboratoires publics ou privés. 


\title{
History as an Obstacle: Impact of Temporal-Based Social Categorizations on Polish-Jewish Intergroup Contact
}

\author{
Michal Bilewicz \\ University of Warsaw
}

\begin{abstract}
Two studies examined the role of temporal-based social categorizations for attitude change during intergroup contact between Polish and Jewish students. In Study 1 ( $N=190$ Polish students), a cross-sectional analysis showed that contact focused on contemporary issues had positive effects on both outgroup attitudes and perceived similarity to the outgroup. No such effects were observed when groups talked about past issues. Study $2(N=97$ Jewish students) demonstrated this effect experimentally when 'historical' and 'contemporary' issues were discussed during contact. Contact about the present generated more positive attitudes toward contact partners and (unlike contact about the past) toward the generalized outgroup. The present findings are discussed in the context of common ingroup identity model and collective guilt research.
\end{abstract}

KEYWORDS anti-Semitism, contact hypothesis, intergroup contact, prejudice

\begin{abstract}
'EVERY generation, by virtue of being born into a historical continuum, is burdened by the sins of their fathers as it is blessed with the deeds of the ancestors', wrote philosopher Hannah Arendt in the postscript to her famous book about Eichmann's trial (Arendt, 1994, p. 298). Indeed, historical events often shape current intergroup perceptions by framing the social categorizations employed. This article presents two studies examining perceptions of history as constraints on successful contact between two groups with a conflicted past.
\end{abstract}

\section{Conditions of bias-reducing intergroup contact}

Since Gordon Allport's book, The Nature of Prejudice (1954), intergroup contact has been considered to be one of the best strategies to reduce prejudice, intergroup anxiety, and other obstacles to improved intergroup relations. Allport argued that in order to establish positive intergroup interaction, four prerequisite conditions have to be fulfilled: equal status, intergroup cooperation, common goals, and support from authorities. Pettigrew $(1997,1998)$ added a fifth condition for successful contact: friendship potential during the intergroup encounter itself.

\footnotetext{
$\overline{\text { Author's note }}$

Address correspondence to Michal Bilewicz, Wydzial Psychologii, Uniwersytet Warszawski, ul. Stawki 5/7, 00-183, Warszawa, Poland [email: bilewicz@psych.uw.edu.pl]
} 
Numerous researchers have examined the cognitive mechanisms that mediate or moderate the positive effects of intergroup contact (Brewer \& Miller, 1988; Dovidio, Gaertner \& Kawakami, 2003; Hewstone, 1996; Hewstone \& Brown, 1986; Wilder, 1986). While Brewer and Miller (1988) stressed the role of personalized cognitions about outgroup members in effective intergroup contact (see also Miller, 2002), other researchers have claimed that salient intergroup categories during contact are necessary to reduce prejudice and increase positive attitudes toward the outgroup as a whole (Brown, Vivian, \& Hewstone, 1999; Hewstone \& Brown, 1986; Islam \& Hewstone, 1993; Voci \& Hewstone, 2003; Wilder, 1986). Those researchers who emphasize the importance of intergroup categorization suggest that conditions promoting personalization are unlikely to result in positive contact effects because the link between the specific exemplar and social category is undermined. Indeed, considerable research has demonstrated that how a target is categorized is of considerable importance for responses to that individual (Schmitt, Silvia, \& Branscombe, 2000). Research on self-categorization has illustrated how increases in category inclusiveness reduces perceived intergroup differences (Haslam, Turner, Oakes, McGarty, \& Reynolds, 1998). Likewise, in the common ingroup identity model, inclusion of an outgroup within a more inclusive category improves attitudes toward former outgroup members (Dovidio, Gaertner, \& Kafati, 2000). The common ingroup identity model is relevant to contact hypothesis research because during intergroup contact both groups may create an inclusive superordinate category, which allows members to respond more positively toward those previously categorized as outgroup members. Common ingroup identity theorists have suggested that category inclusiveness may be an important mediator of the effectiveness of contact (Ellers \& Abrams, 2004; Dovidio et al., 2003).

\section{The psychology of intergroup history}

Perceptions of intergroup history have received little attention from psychologists until quite recent theorizing concerning its consequences for collective guilt (Branscombe, Doosje, \& McGarty, 2002; Doosje, Branscombe, Spears, \& Manstead, 1998; Wohl, Branscombe, \& Klar, 2006), attributions for historical intergroup actions (Doosje \& Branscombe, 2003) and social representations of history (Liu \& Hilton, 2005; Liu, Wilson, McClure, \& Higgins, 1999). Making intergroup history salient can elicit collective emotions, which can be distinguished from emotions experienced when personal identity is salient. Once historical intergroup categories are made salient by reminding participants of some negative behaviors performed by past ingroup members, the explanations for negative historical behaviors on the part of ingroups and outgroups significantly differ. For high identifying group members, this attributional bias is accompanied by greater perceived outgroup homogeneity and larger perceived differences between the groups (Doosje et al., 1998, Study 2; Doosje \& Branscombe, 2003, Study 2).

People can employ several different strategies when they are confronted with a negative aspect of their group's history. Liu and Hilton (2005) argued that people can avoid the negative positioning implied by their group's history by seeking a higher level of identification, (e.g. as Europeans instead of as Germans) and Branscombe, Slugoski, and Kappen (2004) noted that people can also seek a lower level of identity (e.g. the personal level) as a means of avoiding the negative implications of their group's historical actions. Thus, either increasing or decreasing the level of inclusiveness from the intergroup level can allow people to shape contemporary intergroup perceptions without being constrained by their group's troubled past. The current research explores how level of identity inclusiveness influences the effect of intergroup contact on attitudes toward outgroup members.

\section{Poles and Jews: Conflicted memories and prejudice}

Polish-Jewish encounters are fertile ground for social psychological studies of intergroup responses. Strong prejudice against the 
outgroup may be seen among members of both groups (Krzeminski, 1993). Relations between Poles and Jews can be characterized in terms of intergroup anxiety, a siege mentality and conspiracy stereotypes (Bar-Tal \& Antebi, 1992; Kofta, 1995). However, since 1945, occasions for contact between members of these groups have been rare. That is why Polish anti-Semitism is usually described as 'anti-Semitism without Jews' (Lendvai, 1971). The same could be said about Israeli attitudes toward Poles. For most of the young members of the Polish and Jewish nations, the basis for intergroup anxiety is the representation of their intergroup history. In contemporary Poland, the core of the stereotype of Jews lies in the ascription of conspiracy motives (Kofta, 1995; Kofta \& Sedek, 2005; Krzeminski, 1993), which is rooted in pre-war anti-Semitism and does not predict contemporary attitudes toward Israelis. Polish 'anti-Semitism without Jews' then seems to be based on the historical, but not on the contemporary, relations between these groups.

During the last decade, increasing PolishJewish contacts have been established. With the opening of Polish borders, Jewish youth from Israel, USA, Canada and other countries have begun visiting places related to the Holocaustsuch as ghettoes, and concentration and death camps. During these visits, some of the Jewish groups have met with young Poles. For most young Poles and Jews, such encounters are a unique opportunity to interact with members of a group about which they feel they know well from historical narratives (Steinlauf, 1997) but with whom they have little personal experience.

\section{Superordinate categories and conflicted past}

Placing two groups who lack previous contact together does not always lead to improved relations. Memories of their conflicted past may be of key importance for understanding why this would be the case. Wohl and Branscombe (2004) showed that reminding American Jews of their traumatic group history (Holocaust) significantly reduced feelings of collective guilt for their group's current actions during the IsraeliPalestinian conflict. Such memories may elicit general feelings of threat-and when interpreted as illegitimate victimization by another group-it can lead to outgroup derogation (Branscombe, Schmitt, \& Harvey, 1999). Additionally, when the threatening victimization history is presented in an intergroup categorization context, then intergroup forgiveness is unlikely and the desired social distance from descendants of the outgroup is greater than when a more inclusive human categorization context is activated (Wohl \& Branscombe, 2005, Experiment 4). Thus, superordinate or inclusive social categories can reduce the effects of a conflicted past on contemporary intergroup relations and may potentially enable successful intergroup contact. Poles and Jews both perceive the German occupation of Poland as the most tragic part of their history, yet both groups categorize the tragedy in a 'group' context rather than a 'humanity' context. Furthermore, most Poles do not perceive their group as bystanders, or co-perpetrators, of anti-Jewish crimes in Poland (Bilewicz, 2004; Steinlauf, 1997), which is why collective guilt may be unlikely among Polish participants when they consider Polish-Jewish relations. On the other hand, Jews may indeed perceive Poles as historical perpetrators, and when categorizing at the intergroup level, may expect Poles to feel guilty; consequently, contact under intergroup conditions may not lead to improved attitudes toward the outgroup.

\section{The context and hypotheses of the present study}

The present studies attempt to link research on the contact hypothesis with theorizing concerning collective guilt. Recent contact perspectives (Brown et al., 1999; Miller, 2002) have focused on temporary social categorizations among groups who lack a shared and violent history. In Study 1 , a temporal perspective on contact is examined by assessing the consequences of categorization based on past or current intergroup relations for intergroup attitudes. Following Wohl and Branscombe (2005), I propose that the effects 
of intergroup contact may differ depending on whether the self is categorized as a member of a historically continuous national group (Poles vs. Jews), or as a member of a contemporary superordinate group ('the young generation' vs. 'the past generation'). Different predictions can be made for the effects of intergroup contact, depending on which of these self categories is salient.

The Common In-group Identity Model (Dovidio et al., 2000) suggests that the construction of a common group identity should redirect destructive ingroup favoritism into positive common ingroup favoritism, which in turn should lead to successful contact. However, researchers stressing the importance of salient categories during intergroup contact (e.g. Hewstone \& Brown, 1986) would predict that only contact that occurs when historical categories are salient should lead to changes in general attitudesthat is, attitudes toward outgroup members in general, not just those members with whom contact has occurred.

Research on collective guilt (Wohl et al., in press; Wohl, \& Branscombe, 2005) indicates that when historically victimized group members categorize at the most inclusive human level, they perceive genocide as more pervasive across human history, and this in turn increases forgiveness of the perpetrator group for their specific harm doing. When the threatening past is presented at the less inclusive intergroup level, it implies that the negative intergroup history continues. Thus, contact focused on contemporary issues should improve general intergroup attitudes by creating more inclusive intergroup perceptions. Specifically, the hypotheses and predictions tested are:

General hypothesis:

(H1) Contact changes intergroup attitudes both toward the specific participants of contact, and to the outgroup in general. This prediction is derived from the long tradition of research noting the prejudice-reducing role of intergroup contact (Allport, 1954; Pettigrew \& Tropp, 2000).

Three more specific predictions are derived from the theoretical assumptions of the common ingroup identity model and collective guilt research:
(H2) Contact focusing on contemporary issues will enable people to perceive themselves not as members of historically conflicted groups, but as members of a common ingroup. As a result, they will perceive outgroup members as more similar to the ingroup. This hypothesis is consistent with the common ingroup identity model (e.g. Dovidio et al., 2000).

(H3) Contact that focuses on contemporary issues can create a common ingroup identity, leading to more positive attitudes toward the outgroup. This hypothesis also stems from the common ingroup identity model.

(H4) When a broad, superordinate category is created (through contact focused on contemporary issues), perceived Holocaust pervasiveness will be increased and this may result in improved Jewish attitudes toward Poles. This prediction comes from collective guilt research (Wohl \& Branscombe, 2005) where inclusive categorization produces more favorable attitudes toward a former perpetrator outgroup.

\section{Overview of studies}

Study 1 was a cross-sectional study performed in four Polish schools in which meetings with young Jews were organized. The topic of student discussions were not determined by the researchers-rather this variable is based on the Polish participants' reports of the main topic discussed during their contact. The study was performed in Polish schools after the contact with Jewish students had taken place. The study tested the link between the temporal dimension of the discussions during the intergroup contact (historical vs. contemporary topics) and attitudes toward Jews (Aberson \& Howanski, 2002), importance of the contact (van Dick et al., 2004), conspiracy stereotypes (Kofta \& Sedek, 2005), perceived antipathy as a form of intergroup anxiety, and attitudes toward material restitution claims for Holocaust victims (Branscombe et al., 2002).

The main aim of Study 2 was to experimentally investigate the patterns that were observed in Study 1 . The second study was performed during the March of the Living in 2004. The March of the Living is an international educational program that brings Jewish teenagers from all over the world to Poland on Holocaust Memorial Day to march from Auschwitz to Birkenau, the 
largest concentration camp complex built during World War II, and then continue to Israel to observe Israel Memorial Day and Israel Independence Day. While in Poland, Jewish teens also visit Warsaw, Krakow and Lublin. Three groups of Jewish students (American, Canadian and Australian) agreed to take part in our encounter program during their stay in Warsaw in 2004. In the experiment, Jewish participants were randomly assigned to one of three conditions. In one condition, the participants engaged in a group discussion about history with young Poles. In another condition, participants engaged in a group discussion about contemporary issues with young Poles. The third condition was a control group where no discussion took place. At the end, all participants filled out a questionnaire that contained measures of perceived similarity, perceived importance of contact, liking of Poles and a scale of siege mentality (Bar-Tal \& Antebi, 1992) assessing intergroup anxiety.

In both studies, reactions to contact were examined-among Poles in Study 1 and among Jews in Study 2 using measures of specific attitudes (toward the partners of contact: Jews and Poles) as well as measures of attitudes toward the outgroup in general.

\section{Study 1}

\section{Method}

Participants Participants were 190 students ( $N=72$ males, $N=118$ females) from four public secondary schools in three Polish cities (Krakow, Otwock and Warsaw). Ages ranged from 15 to 19 years $(M=17.28, S D=0.77)$.

\section{Measures}

Independent variables The main predictor was a quantitative measure of contact (Islam \& Hewstone, 1993). Respondents were asked about the extent of contact they have had with Jews (scale ranging from 0 to 4 or more meetings). The second predictor was the historical vs. contemporary topic of discussion. That is, participants were asked about the main subject of their discussions with the young Jews, namely, were they primarily contemporary or historical issues. The idea of the temporal dimension of contact is reminiscent of making salient historical intergroup events and creating a feeling of historical continuity between the current groups during the meeting.

Dependent variables Among the dependent variables in the study were: a measure of conspiracy stereotyping (Kofta, 1995); a liking measure (scale from $1=I$ do not like young Jews at all to 7 = I like Jews very much); perceived similarity to young Jews ( 1 = I do not feel similar to young Jews at all to $7=$ I feel very similar to young Jews); and willingness to make material restitution for past harm done by the ingroup to the outgroup (participants were asked if Poland should give back pre-war Jewish possessions, with answers ranging from $1=$ not at all to $7=I$ agree very $m u c h$ ). The measure of conspiracy stereotyping was the level of agreement with two hypothetical conspiratory actions by Jews (i.e. Do you think that Jews concoct various plans in secret? and Do you think that Jews generally care only for their own group?) (Kofta \& Sedek, 2005). These statements were significantly correlated $(r=.40, p<.001)$, and their sum constituted the measure of conspiracy stereotyping (scale ranging from 2 = low conspiracy ascription to $14=$ high conspiracy ascription). Participants were asked if they considered contact between young Poles and Jews as important; answers formed a scale from 1 (I do not consider it important at all) to 7 (I consider it very important).

The last measure was a prototypical statement underlying Polish-Jewish intergroup anxiety: participants were asked if they thought that Jews generally do not like Poles, and answers were provided on a scale ranging from 1 (I do not agree at all) to 7 (I agree very much). This dependent measure captures the effects of intergroup contact on intergroup anxiety, which has been shown to be the main mechanism of improving intergroup relations during contact (Islam \& Hewstone, 1993).

\section{Results}

Mere contact In order to test the first hypothesis, correlations between the main variables were examined. As predicted, intergroup contact significantly affected attitudes toward the 
outgroup and its members. Quantity of contact correlated with perceived similarity to outgroup members $(r=.35, p<.0001)$, such that with higher levels of contact there was more perceived similarity between the groups. Quantity of contact also correlated with liking $(r=.32$, $p<.0001)$. With more contact, there was greater liking of outgroup members. Both of these variables assessed attitudes toward the specific partners of contact. Measures of more general anti-Jewish attitudes were not related to the quantity of contact however. Measures of perceived importance of contact $(r=.08$, $p=.268)$, willingness to fulfill material restitution $(r=.05, p=.516)$, conspiracy stereotypes $(r=$ $-.07, p=.332)$ and general intergroup anxiety $(r=-.08, p=.268)$ were also not correlated with the quantity of contact (see Table 1 for descriptive statistics). Quantity of contact and topic of discussion were significantly correlated $(r=.58, p<.0001)$ : those Polish participants who had more meetings with young Jews talked more about contemporary than historical issues.

History \& presence: Content of contact A oneway analysis of variance (ANOVA) revealed a main effect of the temporal dimension of contact on perceived similarity $(F(2,177)=5.13$, $p<.007)$, liking $(F(2,178)=4.26, p<.02)$, and intergroup anxiety $(F(2,178)=4.48, p<.02)$. When the contact is focused on contemporary topics, it tends to be associated with more positive intergroup relations. However, if discussion is concentrated on history, then generally these positive effects of contact disappear. Polish students talking with young Jews mainly about history felt more disliked by Jews $(M=4.64, S D=2.18)$ than did those who talked about contemporary matters $(M=3.49, S D=1.69)(t(88)=3.19$, $p<.005)$. Those who talked about history ascribed more of the conspiracy stereotype to Jews in general $(M=8.76, S D=3.40)$, while for contemporary discussion: $(M=7.27, S D=3.05)$, $(t(88)=2.16, p<.05)$, and showed less liking than those who talked with Jews about the present (historical: $M=3.79, S D=1.80$ and contemporary: $M=4.67, S D=1.61, t(88)=-2.50$, $p<.05)$.

Positive effects of contact (compared to the control condition) were significant on such measures as perceived similarity and liking, but only in groups that talked about contemporary issues: for liking (no contact: $M=3.96, S D=$ 1.60 and contemporary discussion: $M=4.67$, $S D=1.61, t(148)=2.64, p<.01)$, and for perceived similarity (no contact: $M=3.46$, $S D=1.84$ and contemporary discussion: $M=4.44$, $S D=1.69, t(148)=3.44, p<.001)$. When young Poles talked about history, their liking of the other group did not increase compared to the control condition (no contact: $M=3.96$, $S D=1.60$ and historical discussion: $M=3.79$, $S D=1.80, t(122)=-0.50, p=.62)$, and they perceived themselves as less similar to young Jews compared to participants who did not meet Jews (no contact: $M=3.46 ; S D=1.84$ and historical discussion: $M=4.00 ; S D=2.00$, $t(121)=1.39, p=.17)$.

\section{Discussion: History and personalized contact}

Results of the first study offered support for the contact hypothesis. Correlational analyses

Table 1. Mean liking, perceived similarity, conspiracy ascription and intergroup anxiety by topic of discussion among Poles (Study 1)

\begin{tabular}{|c|c|c|c|c|c|c|c|}
\hline \multirow[b]{3}{*}{ Measure } & \multicolumn{6}{|c|}{ Topic of discussion } & \multirow[b]{3}{*}{$F$} \\
\hline & \multicolumn{2}{|c|}{ Historical } & \multicolumn{2}{|c|}{ Contemporary } & \multicolumn{2}{|c|}{ No contact } & \\
\hline & $M$ & $S D$ & $M$ & $S D$ & $M$ & $S D$ & \\
\hline Liking & 3.79 & 1.80 & 4.67 & 1.61 & 3.96 & 1.60 & $F(2,178)=4.26, p<.02$ \\
\hline Perceived similarity & 4.00 & 2.00 & 4.44 & 1.69 & 3.46 & 1.84 & $F(2,177)=5.13, p<.007$ \\
\hline Conspiracy ascription & 8.76 & 3.40 & 7.27 & 3.05 & 7.71 & 2.74 & $F(2,177)=1.64, p=.74$ \\
\hline Intergroup anxiety & 4.64 & 2.18 & 3.49 & 1.69 & 3.92 & 1.61 & $F(2,178)=4.48, p<.02$ \\
\hline
\end{tabular}


indicated that higher amounts of contact predicted greater liking and perceived similarity to the outgroup. At the same time, the results revealed a significant problem described by Hewstone (1996) and other researchers dealing with personalization in contact (Brewer \& Miller, 1988; Rose, 1981), namely, the problem of generalization. Contact does not seem to lead to changes in attitudes toward the outgroup as a whole (e.g. conspiracy ascription or readiness to fulfill material restitution claims), but only toward specific outgroup members.

Further analyses revealed that the positive effects of contact were driven by certain contact qualities, namely, the issues discussed during the encounter. Among Polish participants who discussed contemporary matters with Jews, contact was associated with positive feelings toward the outgroup. Contact, in this case, produced increased liking and the perception of increased similarity to outgroup members.

No positive effects of contact were found among participants whose contact with Jews made historical social categories salient. Such 'encounters about history' did not increase liking or perceived similarity to the outgroup. Furthermore, this kind of contact led to higher ascription of the conspiracy stereotype to Jews and more intergroup anxiety.

The first study showed that only 'encounters about the present' are correlated with positive outcomes. The historical issues discussed during the meeting worsened intergroup attitudes. This kind of contact could position Polish students as descendants of historical bystanders and perpetrators. However, if conflicted history is a universal obstacle to improved attitudes via intergroup contact, then contact on historical issues should also fail to reduce prejudice among Jewish participants. To better examine whether the content of the encounters is a causal factor, a second study was conducted where the discussion topic could be randomly assigned.

\section{Study 2}

\section{Method}

Participants Participants $(N=43$ males, $N=54$ females) were recruited from the 'March of the
Living' Jewish groups visiting places where Jews were murdered during the Holocaust. They were Jewish students aged 15 to 18 years $(M=16.67$, $S D=0.82$ ) from three countries: USA, Canada and Australia.

\section{Treatments and measures}

Independent variables and procedure The major treatment was experimentally manipulated contact. Participants either did have intergroup contact (47 participants took part in a meeting) or did not (50 participants did not take part in a meeting). In the contact condition, the topic of discussion was manipulated by instructions given to participants at the beginning. Jewish students were divided into small groups (eightten people), each of which was accompanied by two Polish students. The discussion topics concentrated either on historical matters (e.g. 'What do you know about the history of the Holocaust?', 'Do you learn about the history of Jews at school?', 'What do you know about Polish-Jewish relations in the past?') or on contemporary matters (e.g. 'Are you interested in politics?' 'What are your opinions about it?', 'What is different in our countries?', 'What is the most important thing in your life?'). Participants were randomly assigned to one of the discussion topic groups, where they were given one hour to discuss the subject they had been assigned. After the meeting, all of the Jewish participants completed the dependent measures.

Dependent variables Similar dependent measures were used as in Study 1: perceived similarity to outgroup on a 7-point scale ('Overall, how similar would you rate yourself to young Poles?'), liking on a 7-point scale ('Do you think that you like young Poles?') and perceived importance of the contact ('Do you think that meetings of Polish and Jewish youth are important?'), also on a 7-point scale. Additionally, two items assessing feelings of threat from generalized outgroups was included-using items taken from Bar-Tal and Antebi's (1992) measure of siege mentality in Israel: 'Do you agree that there is still strong hatred of Jews in the world?' and 'Do you agree that anti-Semitism exists all over the world, even if not expressed explicitly?' The two items were 
correlated $(r=.42, p<.001)$, and their summed value captures perceived anti-Semitism.

Perceived pervasiveness of genocide has been shown to be an important mediator between social categorization and responses to the historical perpetrator group (Wohl \& Branscombe, 2005). Participants in the current study were asked whether they thought that the Holocaust was an isolated event or if it could recur. Answers ranged from 1 (not at all) to 7 (very much agree).

\section{Results}

Mere contact Effects of mere contact on specific and general attitudes toward outgroup members were tested by comparing the means between the groups that had contact with Polish students and the one that did not have contact. Similar to Study 1, there were significant differences in liking $(t(87)=8.06$, $p<.001)$, and perceived similarity $(t(89)=6.26$, $p<.001)$. Jewish participants who met young Poles, showed higher levels of liking $(M=5.81$, $S D=1.19)$ than did those who did not have contact in a meeting $(M=3.40, S D=1.61)$, and they perceived themselves as more similar to young Poles $(M=5.02, S D=1.26)$ in the meeting condition compared to the no meeting case $(M=3.27, S D=1.40)$.

Significant effects of contact were also observed on measures that indicate general attitudes toward the outgroup. After a meeting, Jewish participants perceived contact with Poles as more important $(M=6.51, S D=0.93)$ compared to the Jewish participants in the no meeting condition $(M=5.98, S D=1.19)(t(93)=-2.32$, $p<.03)$. Interestingly, the Jewish participants who met young Poles perceived less anti-Semitism on average $(M=11.17, S D=2.30)$ than did those who did not meet Poles $(M=12.39$, $S D=1.87)(t(93)=2.83, p<.007)$. This measure of perceived anti-Semitism assessed not only attitudes toward Poles, but outgroups in general (non-Jews). In comparing the present results with those obtained with Poles in Study 1, among the Jewish youth contact led to more generalized effects (Islam \& Hewstone, 1993).

History \& present: Content of contact Further analyses were conducted using one-way ANOVA by discussion condition on perceived similarity, liking, perceived importance of the contact, perceived anti-Semitism and perceived Holocaust pervasiveness as dependent variables. As shown in Table 2, the content of the contact had a significant impact on liking, perceived similarity to the outgroup, perceived importance of the contact and perceived anti-Semitism. Only the Holocaust pervasiveness measure did not significantly vary by content condition $(F(2,92)=$ $.60, p=.55)$. On every dependent measure the pattern seemed to be the same: discussions about history inhibited the positive effects of contact found among those who discussed contemporary issues. This is consistent with Wohl and Branscombe (2005) who found that Jewish participants who categorized at the intergroup level expressed more negative attitudes toward contemporary outgroup members (Germans) than those who categorized at a more inclusive level.

Planned contrasts comparing the historical condition and the control condition revealed that those who discussed the historical topics did

Table 2. Mean liking, perceived similarity, perceived anti-Semitism and perceived importance of contact by topic of discussion among Jews (Study 2)

\begin{tabular}{|c|c|c|c|c|c|c|c|}
\hline \multirow[b]{3}{*}{ Measure } & \multicolumn{6}{|c|}{ Topic of discussion } & \multirow[b]{3}{*}{$F$} \\
\hline & \multicolumn{2}{|c|}{ Historical } & \multicolumn{2}{|c|}{ Contemporary } & \multicolumn{2}{|c|}{ No contact } & \\
\hline & $M$ & $S D$ & $M$ & $S D$ & $M$ & $S D$ & \\
\hline Liking & 5.33 & 1.35 & 6.19 & 0.89 & 3.40 & 1.61 & $F(2,86)=36.11, p<.001$ \\
\hline Perceived similarity & 4.71 & 1.31 & 5.27 & 1.18 & 3.27 & 1.40 & $F(2,88)=20.86, p<.001$ \\
\hline Perceived anti-Semitism & 5.92 & 1.88 & 5.30 & 1.25 & 6.19 & 0.93 & $F(2,92)=6.29, p<.005$ \\
\hline Contact importance & 6.24 & 1.136 & 6.73 & 0.67 & 5.98 & 1.19 & $F(2,92)=4.22, p<.03$ \\
\hline
\end{tabular}


not differ significantly from those who did not have any contact on the measure of perceived anti-Semitism $(t(92)=-.99, p=.32)$ (respectively $M=5.92, S D=1.88$ for historical condition and $M=6.19, S D=.93$ for no contact condition), or in Holocaust pervasiveness $(M=4.57, S D=1.53$ for historical condition and $M=5.04, S D=1.90$ for no contact condition) $(t(92)=-.97, p=.33)$. The intergroup contact that revolved around the past had no effect on the perceived importance of contact compared to the no contact condition (respectively $M=6.24, S D=1.13$ and $M=5.98$, $S D=1.19)(t(92)=.93, p=.354)$. However, such contact had a significant effect on perceived similarity to the outgroup $(t(88)=4.11, p<.001)$, and the liking $(t(86)=5.24, p<.001)$. After the meeting about history, Jewish participants perceived a higher degree of similarity to the outgroup $(M=4.71, S D=1.31$ for historical condition and $M=3.27, S D=1.40$ for no contact condition) and more liking $(M=5.33, S D=1.35$ for historical condition and $M=3.40, S D=1.61$ for no contact condition) than those who did not meet young Poles.

Comparing to the control group, the contact that revolved around contemporary issues had a significant effect not only on such measures as perceived similarity to the outgroup $(t(88)=6.10$, $p<.001)$, and liking $(t(86)=8.12, p<.001)$, but also had an effect on perceived anti-Semitism $(t(92)=-3.54, p<.002)$, and the perceived importance of contact $(t(92)=2.90, p<.01)$. Participants who talked about contemporary issues perceived themselves as more similar to Poles than those who did not have a meeting $(M=5.27, S D=1.18$ for contemporary condition and $M=3.27, S D=1.40$ for no contact condition), they liked Poles more (respectively $M=6.19$, $S D=.89$ and $M=3.40, S D=1.61)$ and perceived contact as more important $(M=6.73, S D=.67$ and $M=5.98, S D=1.19$ for no contact condition). Intergroup contact about contemporary issues had no effect on Holocaust pervasiveness compared to the group without contact $(t(92)=-.79$, $p=.43),(M=4.68, S D=1.97$ for contemporary condition and $M=5.04, S D=1.90$ for no contact condition).

Planned comparisons directly compared the contact about contemporary issues condition with the historical issues contact condition.
Contact concerning contemporary topics led to significantly higher liking $(M=6.19, S D=.89)$ than contact concerning historical topics $(M=5.33, S D=1.35)(t(86)=2.13, p<.02)$. The same is true of more general attitudes, such as perceived anti-Semitism $(t(92)=-2.07$, $p<.05)$. Contact about contemporary issues led participants to perceive less anti-Semitism $(M=5.30, S D=1.25)$ than did contact about historical issues $(M=5.92, S D=1.88)$. No significant difference was found between the two experimental conditions on perceived similarity $(t(88)=1.43, p=.16)$, Holocaust pervasiveness $(t(92)=.20, p=.84)$, and the perceived importance of contact $(t(92)=1.58$, $p=.12$ ). Both groups (participants who had contact about contemporary issues and those who talked mainly about history) perceived outgroup members as quite similar to the ingroup $(M=5.27, S D=1.18$ for contemporary condition and $M=4.71, S D=1.31$ for historical condition). Both of the groups perceived the Holocaust as generally pervasive $(M=4.68, S D=$ 1.97 for contemporary condition and $M=4.57$, $S D=1.53$ for historical condition).

\section{Holocaust pervasiveness and contact}

Holocaust pervasiveness has been reported as a mediator between the level of categorization and collective guilt and forgiveness of the perpetrator category (Wohl \& Branscombe, 2005). Because of the lack of effect of contact on Holocaust pervasiveness, the mediational hypothesis could not be tested. One reason for this may be the way the question about Holocaust pervasiveness was formulated. In Wohl and Branscombe's (2005) work, the measure was clearly about the pervasiveness of genocide in general. In the present study, participants could understand it either as genocide in general, or specifically, in reference to an anti-Semitic genocide. Future studies using a more straightforward measure of pervasiveness of genocide should investigate this issue in detail.

\section{General discussion}

The present research involved cross-sectional and experimental evaluations of the general idea that not only the form but also the content 
of contact affects the outcome of intergroup encounters. Numerous dimensions of contact have been examined in prior research, such as the amount of contact, the intimacy of the contact and interdependence or salience of group membership (Brown et al., 1999). The aim of the current research was to add a new dimension based on categorization processes: the temporal social categorizations evoked during contact. The way people perceive their contact partners-as their temporal ingroup (living in the same time, being contemporary to each other), or as a social and ethnic outgroup (being members of historically opposed nations)-determines the effects of contact. Study 1 showed that among Polish students, discussions about historical issues have no positive effects at all, while discussions about contemporary matters create more positive attitudes toward contact partners and enable people to perceive important similarities across the groups. Study 2 showed that for Jewish students, contact led to more positive attitudes toward the general outgroup, as well as toward the specific outgroup members with whom the contact took place. Again, such effects were observed only among those participants who talked about contemporary issues. Discussions about history led to positive attitudes toward contact partners, but not toward generalized outgroup members.

Both studies lead to similar conclusions, however two important differences should be underlined: (1) the Polish-Jewish encounters occurred in Poland, so they had a minoritymajority character (young Jews were visitors in a mono-ethnic country); and (2) concentrating on the past could mean something different for both groups, because Polish and Jewish history are not equivalent.

The Polish and Jewish students in Study 2 met during the 'March of the Living' event in which Jewish students come to Poland to confront the history of the Holocaust. It may be pointed out then that for them the historical categories were constantly salient. During the meeting, Jews appeared as a minority in the majority context of a Polish society. As Liebkind, Nyström, Honkanummi, and Lange (2004) demonstrate, minorities have more positive intergroup attitudes than do majorities. This is also true when we compare the results on liking and perceived similarity between Study 1 and Study 2. Jews visiting Poland are in a minority position and are surrounded by potential contact partners. This cannot be said about the Polish students. When young Jews encounter young Poles during student meetings, they may easily generalize contact effects because of the similarity between contact partners and other Poles they see during their stay. Such a comparison elicits the perception of the contact partners' typicality, and leads to generalization of the contact effect (as seen in Study 2). In contrast, Polish students encountering young Jews have no opportunity to generalize their perceptions-they may not therefore perceive their contact partner as a typical member of his/ her group. Study 1 showed such change among Poles in attitudes toward the contact partners, but not toward the general outgroup.

The second difference distinguishing between research showing how history reminders can evoke collective guilt (Branscombe et al., 2002) and the current findings concerns the extent to which dehumanization of an outgroup may occur as a means of avoiding collective guilt in accused perpetrator groups. In the current research, Polish students who talked about the past had to face uncomfortable information about their ingroup's behavior. This might encourage minimization of the harm done, defensive reductions in the ingroup's responsibility for the harm, or actual dehumanization of past victims (see Branscombe \& Miron, 2004). Such processes might well extend to more negative attitudes toward contemporary outgroup members as observed in Study 1. In contrast, the 'memory of siege' that shapes Jewish responses to history involves an elicitation of general fear toward militant outgroups (see Bar-Tal \& Antebi, 1992), but it may not affect attitudes toward specific outgroup members. Such a distinction helps in understanding why talking about history in Study 2 did not affect the Jewish participants' attitudes toward generalized outgroups after contact, but at the same time produced an increase in liking and perceived similarity to contact partners. 
While the two studies presented in this article reveal similar patterns in responses to historical and contemporary topics of contact, they differ in terms of the general position of both contact groups. The historical position of Poles could be seen as co-victim (German occupation), bystander (during the Holocaust) or perpetrator (pre-war pogroms)-some of which are more likely to open the door to processes of collective guilt and reparations than are others (Wohl et al., 2006). For the Jewish participants, the historical position of the ingroup is rather more clear-cut-with reminders of victimization eliciting processes of intergroup threat and guilt anticipation which may influence their perception of the past and present (Wohl \& Branscombe, 2004). The similarity of the effects obtained in both the present studies suggests that when it comes to intergroup contact, the same mechanism may be underlying perception of conflicted intergroup history for the descendants of both victims and perpetrators or bystanders.

The main aim of both studies was to examine the impact of historical context of contact as a categorization process for intergroup attitudes. Contact with salient contemporary categories, which implies building a common temporal ingroup identity, enables prejudice reduction. At the same time, it enables perceivers to have more positive feelings toward specific contact partners. In contrast, contact with salient historical categories leads to opposite responses. When participants are made aware of their history, they respond based on the historical positions of their groups. Intergroup contact may be unlikely to change that. The present findings demonstrate that feelings of being victimized by generalized outgroups, or stereotyped as conspirators, will not rapidly shift as a function of such brief contact.

The present findings may have important practical consequences. Polish-Jewish relations are not unique and it may be argued that most contemporary ethnic conflicts are based, at least in part, on conflicted representations of history. In times of conflict, collective guilt is very rare; such periods of increased ingroup favoritism also affect subsequent perceptions of history
(Roccas, Klar, \& Liviatan, 2004). A possible positive solution to history-based conflicts is the open dialogue between members of both groups, but only if such dialogue focuses on the present, and not on the bitter history.

\section{Acknowledgements}

The research reported in this article was funded by research grant BST 1069/2005 from the Faculty of Psychology, University of Warsaw, and the Foundation for Polish Science Scholarship. Adam Ostolski, Adrian Wojcik and Aleksandra Wysocka assisted in data collection and coding. The author would like to thank Bettina Spencer, Jasia Pietrzak, Mirek Kofta, Nyla Branscombe, and two anonymous reviewers for their fruitful comments on earlier drafts of this paper. The author also acknowledges helpful discussions with Emanuele Castano.

\section{References}

Aberson, C. L., \& Howanski, L. M. (2002). Effects of self-esteem, status, and identification on two forms of ingroup bias. Current Research in Social Psychology, 13, 225-243.

Allport, G. W. (1954). The nature of prejudice. Reading, MA: Addison-Wesley.

Arendt, H. (1994). Eichmann in Jerusalem. A report on the banality of evil. Revised and enlarged edition. New York: Penguin.

Bar-Tal, D., \& Antebi, D. (1992). Siege mentality in Israel. International Journal of Intercultural Relations, 16, 251-275.

Bilewicz, M. (2004) Wyjaśnianie Jedwabnego: antysemityzm i postrzeganie trudnej przeszlości [Explaining Jedwabne: Anti-semitism and the perception of difficult past]. In I. Krzemiński (Ed.), Antysemityzm w Polsce i na Ukrainie. Raport z badań, (pp. 248-269). Warszawa: Scholar.

Branscombe, N. R., Doosje, B., \& McGarty, C. (2002). Antecedents and consequences of collective guilt. In D. M. Mackie \& E. R. Smith (Eds.), From prejudice to intergroup emotions (pp. 49-67). New York: Psychology Press.

Branscombe, N. R., \& Miron, A. M. (2004). Interpreting the ingroup's negative actions toward another group: Emotional reactions to appraised harm. In L. Z. Tiedens \& C. W. Leach (Eds.), The social life of emotions (pp. 314-335). New York: Cambridge University Press. 
Branscombe, N. R., Schmitt, M. T., \& Harvey, R. D. (1999). Perceiving pervasive discrimination among African Americans: Implications for group identification and well-being. Journal of Personality and Social Psychology, 77, 135-149.

Branscombe, N. R., Slugoski, B., \& Kappen, D. M. (2004). The measurement of collective guilt: What it is and what it is not. In N.R. Branscombe \& B. Doosje (Eds.), Collective guilt: International perspectives (pp. 16-34). New York: Cambridge University Press.

Brewer, M. B., \& Miller, N. (1988). Contact and co-operation: When do they work? In P. Katz \& D. Taylor (Eds.), Eliminating racism: Profiles in controversy (pp. 315-326). New York: Plenum Press.

Brown, R., Vivian, J., \& Hewstone, M. (1999). Changing attitudes through intergroup contact: The effects of group membership salience. European Journal of Social Psychology, 29, 741-764.

Doosje, B., \& Branscombe, N. R. (2003).

Attributions for the negative historical actions of a group. European Journal of Social Psychology, 33, 235-248.

Doosje, B., Branscombe, N., Spears, R., \& Manstead, A. S. R. (1998). Guilty by association: When one's group has a negative history. Journal of Personality and Social Psychology, 75, 872-886.

Dovidio, J. F., Gaertner, S. L., \& Kafati G. (2000). Group identity and intergroup relations: The Common InGroup Identity Model. In S. R. Thye, E. J. Lawler, M. W. Macy, \& H. A. Walker (Eds.), Advances in group processes (Vol. 17, pp. 1-34). Stamford, CT: JAI.

Dovidio, J. F., Gaertner, S. L., \& Kawakami, K. (2003). Intergroup contact: The past, present, and the future. Group Processes $\mathcal{E}$ Intergroup Relations, 6, 5-21.

Ellers, A., \& Abrams, D. (2004). Come together: Longitudinal comparisons of Pettigrew's Reformulated Intergroup Contact Model and the Common Ingroup Identity Model in Anglo-French and Mexican-American contexts. European Journal of Social Psychology, 34, 229-256.

Haslam, S. A., Turner, J. C., Oakes, P. J., McGarty, C., \& Reynolds, K. J. (1998). The group as a basis for emergent stereotype consensus. In W. Stroebe \& M. Hewstone (Eds.), European Review of Social Psychology (Vol. 8, pp. 203-239). New York: Wiley.

Hewstone, M. (1996). Contact and categorization: Social psychological interventions to change intergroup relations. In C. N. Macrae,
C. Stangor, \& M. Hewstone (Eds.), Stereotypes and stereotyping (pp. 323-368). New York: Guilford.

Hewstone, M., \& Brown, R. (Eds.). (1986). Contact and conflict in intergroup encounters. Oxford, UK: Blackwell.

Islam, M. R., \& Hewstone, M. (1993). Dimensions of contact as predictors of intergroup anxiety, perceived outgroup variability, and outgroup attitude: An integrative model. Personality and Social Psychology Bulletin, 19, 700-710.

Kofta, M. (1995). Stereotype of a group as-a-whole: The role of diabolic causation schema. Polish Psychological Bulletin, 26, 83-96.

Kofta, M., \& Sedek, G. (2005). Conspiracy stereotypes of Jews during systemic transformation in Poland. International Journal of Sociology, 35, 40-64.

Krzeminski, I. (1993). Anti-Semitism in today's Poland. Patterns of Prejudice, 27, 127-135.

Lendvai, P. (1971). Anti-Semitism without Jews: Communist Eastern Europe. New York: Doubleday.

Liebkind, K., Nyström, S., Honkanummi, E., \& Lange, A. (2004). Group size, group status and dimensions of contact as predictors of intergroup attitudes. Group Processes and Intergroup Relations, 7, 145-159.

Liu, J. H., \& Hilton D. (2005). How the past weighs on the present: Social representations of history and their role in identity politics. British Journal of Social Psychology, 44, 537-556.

Liu, J. H., Wilson, M. W., McClure, J., \& Higgins, T. R. (1999). Social identity and the perception of history: Cultural representations of Aotearoa/ New Zealand. European Journal of Social Psychology, 29, 1021-1047.

Miller, N. (2002). Personalization and the promise of contact theory. Journal of Social Issues, 58, 387-410.

Pettigrew, T. F. (1997). Generalized intergroup contact effects on prejudice. Personality and Social Psychology Bulletin, 23, 173-185.

Pettigrew, T. F. (1998). Intergroup contact theory. Annual Review of Psychology, 49, 65-85.

Pettigrew, T. F., \& Tropp, L. R. (2000). Does intergroup contact reduce prejudice? Recent meta-analytic findings. In S. Oskamp (Ed.), Reducing prejudice and discrimination: The Claremont symposium (pp. 93-114). Mahwah, NJ: Erlbaum.

Roccas, S., Klar, Y., \& Liviatan, I. (2004). Exonerating cognitions, group identification, and personal values as predictors of collective guilt among Jewish-Israelis. In N. R. Branscombe \& 
B. Doosje (Eds.), Collective guilt: International perspectives (pp.130-147). New York: Cambridge University Press.

Rose, T. L. (1981). Cognitive and dyadic processes in intergroup contact. In D. L. Hamilton (Ed.), Cognitive processes in stereotyping and intergroup behavior (pp. 259-302). Hillsdale, NJ: Erlbaum.

Schmitt, M. T., Silvia, P., \& Branscombe, N. R. (2000). The intersection of self-evaluation maintenance and social identity theories: Intragroup judgment in interpersonal and intergroup contexts. Personality and Social Psychology Bulletin, 26, 1598-1606.

Steinlauf, M. C. (1997). Bondage to the dead: Poland and the memory of the Holocaust. Syracuse: Syracuse University Press.

van Dick, R., Wagner, U., Pettigrew, T. F., Christ, O., Wolf, C., Petzel, T. et al. (2004). Role of perceived importance in intergroup contact. Journal of Personality and Social Psychology, 87, 211-227.

Voci, A., \& Hewstone, M. (2003). Intergroup contact and prejudice toward immigrants in Italy: The mediational role of anxiety and the moderational role of group salience. Group Processes $\mathcal{E}$ Intergroup Relations, 6, 37-54.

Wilder, D. A. (1986). Cognitive factors affecting the success of intergroup contact. In S. Worchel \& W. G. Austin (Eds.), Psychology of intergroup relations (pp. 49-66). Chicago: Nelson-Hall.
Wohl, M. J. A., \& Branscombe, N. R. (2004). Importance of social categorization for forgiveness and collective guilt assignment for the Holocaust. In N. R. Branscombe \& B. Doosje (Eds.), Collective guilt: International perspectives (pp. 284-305). New York: Cambridge University Press.

Wohl, M. J. A., \& Branscombe, N. R. (2005). Forgiveness and collective guilt assignment to historical perpetrator groups depend on level of social category inclusiveness. Journal of Personality and Social Psychology, 88, 288-303.

Wohl, M. J. A., Branscombe, N. R., \& Klar, Y. (2006). Collective guilt: Emotional reactions when one's group has done wrong or been wronged, European Review of Social Psychology, 17, 1-37.

Paper received 28 June 2005; revised version accepted 2 May 2006.

\section{Biographical note}

MICHAL BILEWICZ received his PhD in psychology from the University of Warsaw and currently coordinates the Center for Research on Prejudice at the Faculty of Psychology, University of Warsaw. His main areas of interest include contact hypothesis and infrahumanization. In 2005 he was at the New School for Social Research in New York as a Fulbright Visiting Researcher. 